\title{
Penyuluhan Dan Pelatihan Invisible \& Visible Knowledge Profiling Untuk Meningkatkan Kompetensi Pada SMA Negeri 3 Semarang
}

\author{
Indra Gamayanto ${ }^{1}$, Titien Suhartini Sukamto ${ }^{2}$, Ramadhan Rakhmat $\mathrm{Sani}^{3}$, Sasono Wibowo ${ }^{4}$, Sri \\ Winarno ${ }^{5}$, Asih Rohmani ${ }^{6}$ \\ 1,2,3,4,5,6 Fakultas Ilmu Komputer, Universitas Dian Nuswantoro, Semarang \\ E-mail: ${ }^{1}$ indra.gamayanto@dsn.ac.id, ${ }^{2}$ titien.suhartini@dsn.dinus.ac.id, \\ 3ramadhan_rs@dsn.dinus.ac.id, ${ }^{4}$ sasono.wibowo@dsn.dinus.ac.id, ${ }^{5}$ sri.winarno@dsn.dinus.ac.id, ${ }^{6}$ \\ asih.rohmani@dsn.dinus.ac.id
}

\begin{abstract}
Abstrak
Pendidikan memiliki arti menggabungkan antara pengetahuan dan pengalaman untuk menghasilkan inovasi yang bermanfaat bagi umat manusia. Keduanya saling terhubung satu sama lain dan tidak boleh dipisahkan. Oleh sebab itu, menggabungkan antara pengetahuan dan pengalaman adalah hal mutlak yang seharusnya diterapkan dalam semua lini pendidikan agar siap dalam menghadapi globalisasi dengan level tertinggi. Definisi kesempurnaan adalah menggabungkan antara pengetahuan dan pengalaman sehingga menghasilkan hal-hal inovatif yang bermanfaat dan memberikan kontribusi positif terhadap hidup orang banyak. Artikel ini merupakan penyuluhan dan pelatihan invisible \& visible knowledge profiling yang merupakan dua hal penting yang harus dapat dikembangkan di dalam pendidikan dan dunia kerja. Lebih jauh lagi, artikel ini merupakan pengembangan dari artikel sebelumnya yaitu pelatihan dan implementasi social media profiling. Pengabdian masyarakat yang kami lakukan haruslah berkelanjutan dan terus dikembangkan hingga mencapai tingkat kualitas tertinggi dalam pengetahuan, inilah prinsip yang terdapat pada invisible \& visible knowledge profiling. Hasil dari artikel ini adalah bagaimana car akita meningkatkan kinerja sumber daya manusia yang terdapat di dalam dunia pendidikan, profil lengkap kemampuan dan sumber daya manusia yang ada, klasifikasi dan tahapan apa saja yang seharusnya dapat dilakukan. Konsep dalam artikel ini menggabungkan dengan tiga metode yaitu 3SDP-mendukung komunitas belajar aktif, merancang peluang kepemimpinan, menghasilkan sumber daya pendidikan (yang berasal dari Harvard University), Johari window dan $\mathrm{E}=\mathrm{KM} . \mathrm{C}^{2}$.
\end{abstract}

Kata kunci: Pendidikan, Invisible-visible knowledge, Inovasi, Profiling, Sumber Daya Manusia

\section{Abstract}

Education means combining knowledge and experience to produce innovations that benefit mankind. Both of them are connected to each other and should not be separated. Therefore, combining knowledge and experience is an absolute thing that should be applied in all lines of education in order to be ready to face globalization at the highest level. The definition of perfection is to combine knowledge and experience to produce innovative things that are useful and make a positive contribution to the lives of many people. This article is an extension and training on invisible \& visible knowledge profiling, which are two important things that must be developed in education and the world of work. Furthermore, this article is an extension of the previous article, namely training and implementing social media profiling. The community service that we do must be sustainable and continuously developed to reach the highest level of quality in knowledge, this is the principle contained in invisible \& visible knowledge profiling. The results of this article are how we can improve the performance of human resources in the world of education, a complete profile of existing human capabilities and resources, what classifications and stages should be taken. The concept in this article combines with three methods namely 3SDP - supporting active learning communities, designing leadership 
opportunities, generating educational resources (originating from Harvard University), Johari window and $E=K M . C 2$.

Keywords: Education, Invisible-visible knowledge, Innovation, Profiling, Human Resources

\section{PENDAHULUAN}

Suatu organisasi dapat menganggap IT sebagai 'hal yang sangat diperlukan', sesuatu yang diperlukan untuk tetap dalam bisnis, sementara yang lain mungkin melihatnya sebagai sumber utama peluang strategis, mencari secara proaktif untuk mengidentifikasi bagaimana sistem informasi berbasis TI dapat membantu mereka memperoleh keunggulan kompetitif. Terlepas dari sikap yang diambil, begitu organisasi memulai investasi semacam ini, ada sedikit peluang untuk kembali. Karena TI menjadi lebih kuat dan relatif lebih murah, penggunaannya telah menyebar ke seluruh organisasi dengan cepat. Level yang berbeda dalam hierarki manajemen sekarang menggunakan IT di mana dulunya satu-satunya domain berada di level operasional. Tujuannya sekarang bukan hanya untuk meningkatkan efisiensi tetapi juga untuk meningkatkan efektivitas bisnis dan untuk mengelola organisasi secara lebih strategis. Ketika tugas-tugas manajerial menjadi lebih kompleks, maka sifat dari sistem informasi yang diperlukan berubah dari dukungan terstruktur, rutin ke ad hoc, penyelidikan tidak terstruktur, kompleks di tingkat manajemen tertinggi. Karena itu, kemajuan teknologi memiliki dampak besar pada pengembangan pendidikan. Universitas Harvard, salah satu universitas terbaik di dunia memiliki Pusat Pengembangan Anak: perubahan kolektif, yang mencakup tiga hal penting, antara lain: (1) Melalui dukungan komunitas belajar aktif, (2) merancang peluang kepemimpinan, dan (3) menghasilkan sumber daya pendidikan. Ketiga konsep ini sangat baik jika diterapkan untuk dapat meningkatkan sumber daya manusia. Selain ketiga konsep ini, konsep yang akan digunakan adalah Johari Window dan $\mathrm{E}=\mathrm{K} . \mathrm{MC}^{2}$, kedua konsep ini akan lebih detail untuk menghasilkan bagaimana mengembangkan sumber daya manusia di tingkat pendidikan untuk dapat menghasilkan "baik sampai hebat" sumber daya manusia. Artikel ini merupakan pengembangan dari jurnal sebelumnya yaitu pelatihan dan implementasi social media profiling. Terdapat beberapa hal yang harus kita pahami terlebih dahulu sebelum melangkah lebih jauh. Sheehan, M (2014): "Penelitian di masa depan harus fokus pada desain studi yang lebih mampu menunjukkan tatanan kausal untuk menunjukkan bahwa praktik sumber daya manusia, bila diterapkan dengan benar, secara positif dapat menghasilkan kinerja perusahaan yang lebih tinggi. Minimal, ini panggilan untuk fokus pada pengumpulan data di berbagai titik waktu; (2) Memperkenalkan Perspektif Baru tentang Pengembangan Sumber Daya Manusia Virtual. "Aspek-aspek definisi ini menunjukkan dua poin penting. Pertama, profesional HRD menggunakan kombinasi ide, teknik, dan pendekatan dalam praktik. Kedua, pembelajaran penting untuk kinerja di berbagai tingkat organisasi, dari individu ke kolektif yang lebih besar[1]. Hal ini mengidentifikasi HRD sebagai sistem pembelajaran yang menggunakan pembelajaran formal, seperti kegiatan pembelajaran berbasis kelas dan simulasi yang menumbuhkan pembelajaran perwakilan, serta pembelajaran informal, seperti pembelajaran berbasis pengalaman dan pekerjaan. Dalam praktiknya, membangun sistem pembelajaran dalam suatu organisasi melibatkan negosiasi dengan berbagai pemangku kepentingan yang memiliki kepentingan dalam sistem tersebut. Penerimaan teknologi baru dan mencapai sarana utilitas yang melibatkan pengguna dalam pilihan desain pada berbagai tahap berulang[2]; namun, organisasi harus memiliki kapasitas belajar untuk menghadapi perubahan yang dibawa oleh teknologi[3]. Moussa Boumadan (2020), mengatakan Kegiatan kolaboratif online, tergantung pada persepsi peserta, meningkatkan tidak hanya perkembangan kognitif tetapi juga mendorong perolehan keterampilan seperti kerja tim, sikap kolaboratif, dan memperkaya visi siswa berkat sudut pandang yang berbeda[4]. Charles hodges (2020), mengatakan, Memindahkan instruksi online dapat memungkinkan fleksibilitas pengajaran dan pembelajaran di mana saja, kapan saja, tetapi kecepatan yang diharapkan untuk perpindahan ke instruksi online ini belum pernah terjadi 
sebelumnya dan mengejutkan. Meskipun staf dan tim dukungan kampus biasanya tersedia untuk membantu anggota fakultas mempelajari dan menerapkan pembelajaran online, tim ini biasanya mendukung sekelompok kecil fakultas yang tertarik untuk mengajar secara online[5]. Oleh sebab itu, fleksibelitas dibutuhkan agar proses belajar mengajar dapat berjalan secara efektif dan efesien. Joan Strikwerda-Brown (2008), mengatakan, Kaum muda harus dapat memikul tanggung jawab dengan apa yang mereka lakukan, katakan dan rasakan. Hal ini akan dapat membangkitkan kesejahteraan sebuah bangsa dan masa depan[6]. Bergerak melampaui penerimaan dasar, organisasi dapat fokus pada aspek strategis dan kadang-kadang menantang sistem kompleks saat ini[7],. Masalah utama yang dibahas dalam artikel ini adalah dibutuhkannya pembelajaran yang lebih inovatif dan tepat sasaran, yang menggabungkan antara pengetahuan dan pengalaman, klasifikasi yang lebih jelas mengenai sumber daya manusia dan konsep serta ide inovasi apa saja yang sekiranya dapat dianjurkan untuk diterapkan. Hasil dari jurnal ini adalah: pengembangan kepemimpinan berkualitas tinggi dan sumber daya manusia berdasarkan tiga konsep Universitas Harvard (3SDP-mendukung komunitas pembelajaran aktif, merancang peluang kepemimpinan, memproduksi sumber daya pendidikan)

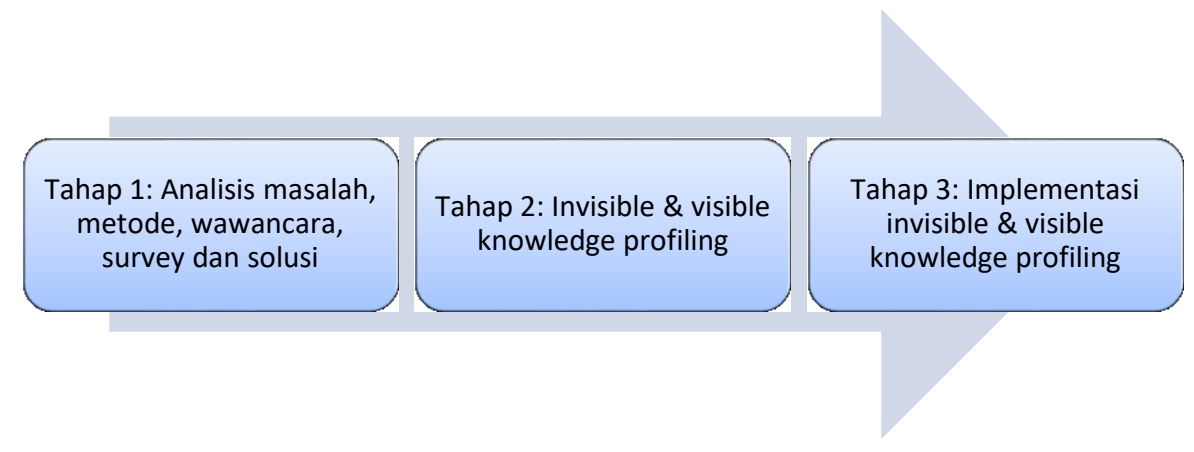

Gambar 1. Proses Penelitian dan Pengabdian masyarakat di SMA Negeri 3 Semarang

Gambar 1, menjelaskan tahapan penelitian, pengabdian dan pengabdian masyarakat di SMA Negeri 3 Semarang. Tahap pertama adalah kami melakukan wawancara untuk menemukan kebutuhan apa saja untuk meningkatkan komptensi di SMA Negeri 3 Semarang, dan mendiskusikan model pelatihan yang diperlukan. Tahap kedua adalah melakukan pelatihan dan pembelajaran secara komprehensif di SMA Negeri 3 Semarang. Tahap ketiga merupakan tahap akhir, kami menjelaskan cara bagaimana hal-hal yang telah dijelaskan tersebut dapat diimplementasikan dalam kehidupan sehari-hari. metode yang kami gunakan dalam mengembangkan pelatihan ini adalah sebagai berikut:

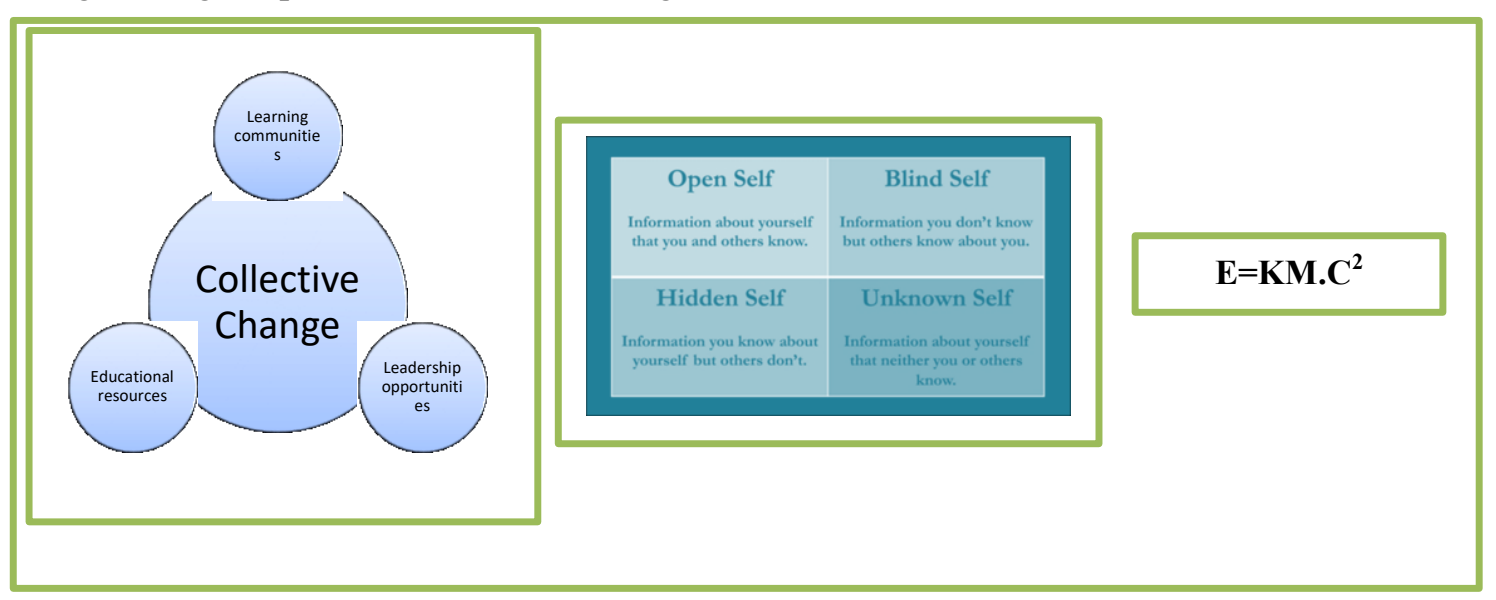

Gambar 2. Metode (1) collective change, (2) Johari windows, (3) formula E=KM.C ${ }^{2}$ 
Gambar 2, menjelaskan metode dan tahapan dalam melakukan pelatihan dan pengabdian, prosesnya adalah sebagai berikut: (1) collective change: (1) Komunitas belajar memberikan ruang dan struktur bagi orang untuk menyelaraskan tujuan bersama. Komunitas yang efektif adalah aspirasi dan praktis. Mereka menghubungkan orang-orang, organisasi, dan sistem yang ingin belajar dan bekerja melintasi batas, sambil meminta anggota bertanggung jawab atas agenda, metrik, dan hasil bersama. Komunitas ini memungkinkan peserta untuk berbagi hasil dan belajar satu sama lain, sehingga meningkatkan kemampuan mereka untuk mencapai kemajuan yang cepat namun signifikan. (2) Diluncurkan pada tahun 2011 oleh lima organisasi mitra di Brazil dan di Harvard, Núcleo Ciência Pela Infância (NCPI) adalah inisiatif kolaboratif yang dirancang untuk memajukan investasi anak usia dini di negara Amerika Latin yang berkembang pesat menghadapi ketidakseimbangan sosial ekonomi yang signifikan. Salah satu fitur paling penting dari kemitraan ini adalah Program Kepemimpinan Eksekutif (ELP) yang dirancang untuk membangun kapasitas para pemimpin dalam pemerintahan dan masyarakat sipil untuk menerapkan ilmu pengembangan anak usia dini ke beberapa masalah sosial paling kompleks di negara mereka. (3) Pusat berusaha untuk menyajikan informasi, terutama informasi ilmiah, (2) Johari window: Berkomunikasi dengan diri sendiri dan orang lain, Perlihatkan diri Anda kepada diri sendiri dan orang lain, Pahami diri Anda dan bagaimana orang lain memandang Anda, Tindakan vs. motivasi[8], (3) Formula E=KM.C2, dimana E: value of company (energy), K: knowledge, M: Marketing, C1: Computer technology, C2: Communication technology. Konsep-konsep ini akan digabungkan dan akan menghasilkan sebuah framework yang disebut: Invisible \& Visible Knowledge Profiling Framework

\section{HASIL DAN PEMBAHASAN}

A. Kegiatan Pengabdian Masyarakat Di SMA Negeri 3 Semarang

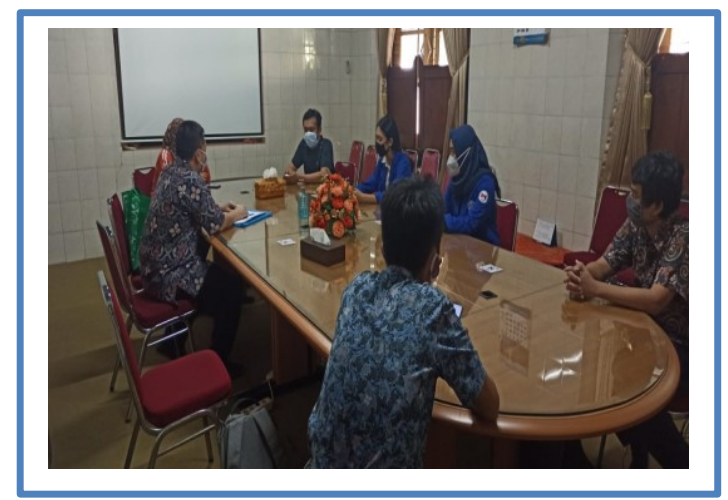

Gambar 3. Proses pertama: wawancara dan mengoleksi data

Pada gambar 3, dijelaskan kami melakukan wawancara dengan SMA Negeri 3 Semarang, Bpk. Sarojo, S.Pd, M.Pd dan Ibu Fitri. Pada hasil wawancara ini, kami menemukan bahwa menggabungkan antara pengetahuan dan pengalaman adalah merupakan hal yang sangat penting dalam menghadapi perubahan dan globalisasi. Oleh sebab itu, dibutuhkan sebuah kerangka strategi dalam menerapkan hal tersebut. 


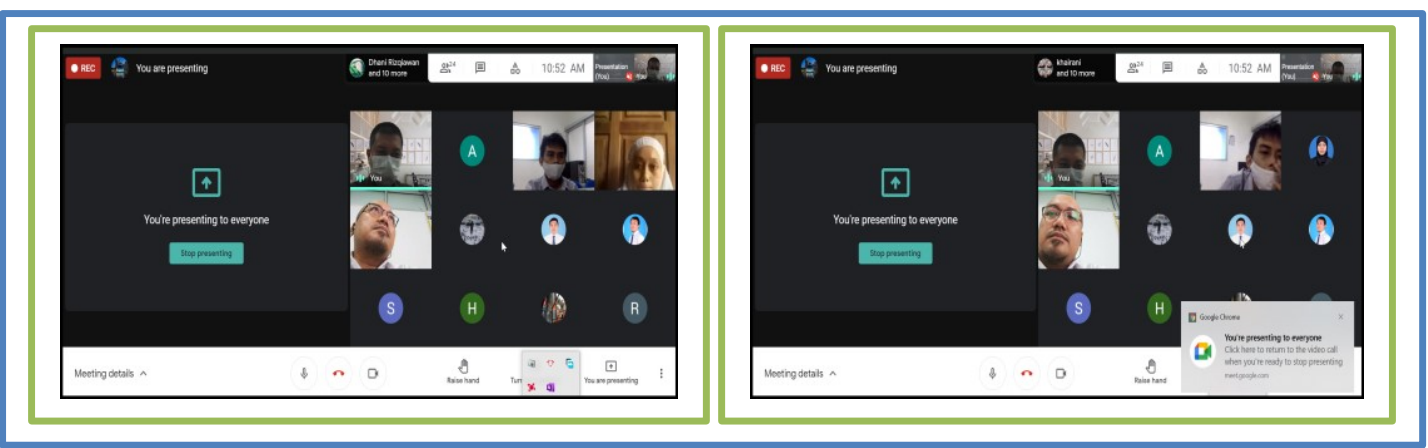

Gambar 4. Proses kedua: penyuluhan dan pelatihan invisible \& visible knowledge profiling

Pada gambar 4, dijelaskan bahwa invisible dan visible merupakan kedua pengetahuan yang perlu dikembangkan, dimana invisible adalah kemampuan atau kompetensi yang diperoleh dari pengalaman, sedangkan visible knowledge adalah pengetahuan yang diperoleh dari pendidikan itu sendiri.

B. Konten Pelatihan: Invisible \& Visible Knowledge Profiling Framework

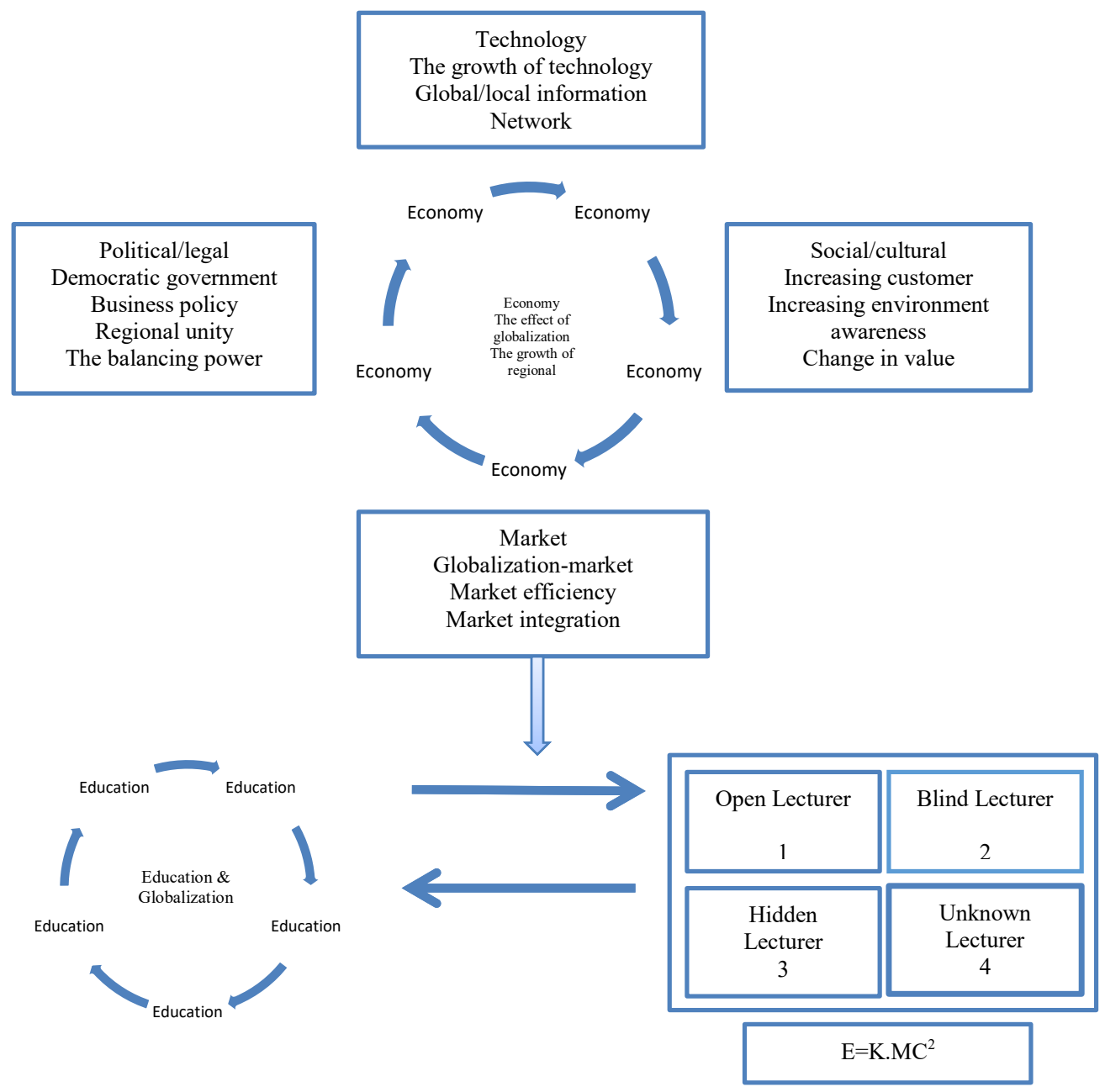




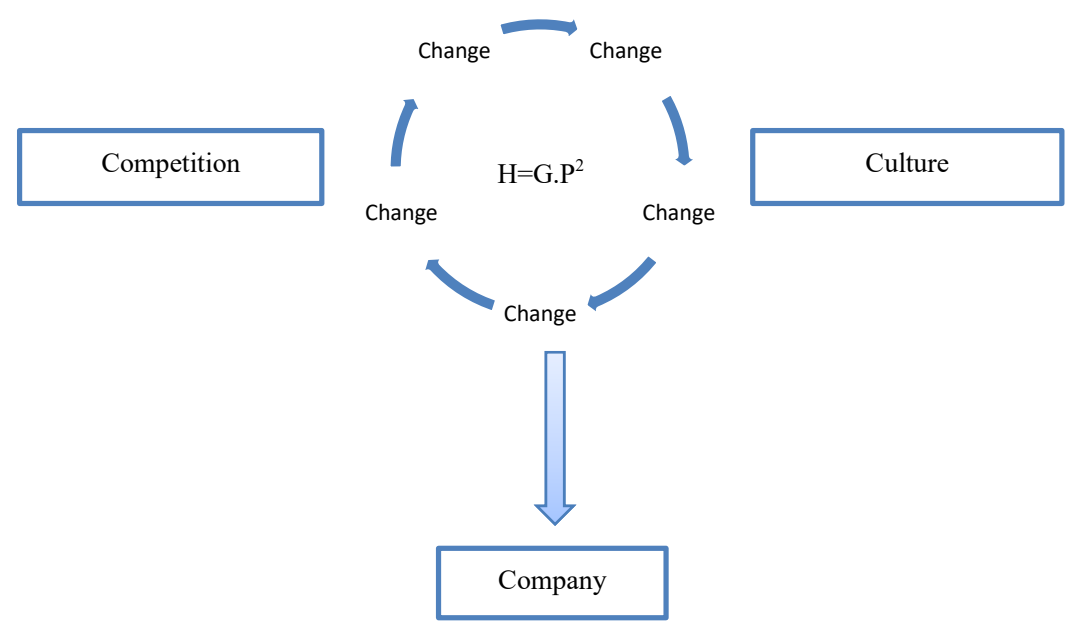

Gambar 5. invisible \& visible knowledge profiling Framework

Gambar 5 menjelaskan, beberapa tahapan dalam penerapan konsep invisible \& visible knowledge profiling, antara lain:

Tahap pertama

memiliki lima bagian penting: teknologi; sosial / budaya; politik / hukum; pasar; ekonomi. Hal ini dapat dijelaskan dengan sangat rinci sebagai berikut:

Bidang Teknologi- kecepatan akses terhadap informasi, inovasi dan kecepatan perkembangan teknologi merupakan salah satu faktor penting yang harus menjadi concern utama dalam pendidikan, karena perubahan ini akan memiliki dampak pada semua proses belajar mengajar. Penggunaan teknologi harus sedemikian efektif dan efesien serta harus terdapat kebiasaan baru dalam proses belajar mengajar yaitu penitikberatkan pada banyaknya penggunaan teknologi dan pengembangan aplikasi khusus proses belajar mengajar.

Bidang Sosial dan Budaya- di sini perlu dipahami dua hal penting yaitu siswa, mahasiswa sebagai konsusmen eksternal dan internal, sedangkan pendidik seperti pendidik, pendidik adalah sebagai konsumen internal. Artinya siswa, mahasiswa selain sebagai konsumen, memiliki fungsi sebagai produk yang harus dibentuk kompetensinya, dikembangkan pengetahuannya dan pengalamannya selama menjalani proses belajar mengajar di tingkat sekolah atau universitas. Di sisi lain, pendidik, pendidik adalah konsumen internal yang juga harus mengembangkan pengetahuannya, dimana pendidik, pendidik adalah jembatan penting antara pengetahuan terbaru yang disalurkan kepada siswa, mahasiswa, setelah itu harus dapat memberikan inovasi dari apa yang diajarkannya. Pendidik, pendidik tidak hanya mengajarkan apa yang "ingin" didengar, tetapi apa yang "perlu didengar", inilah yang disebut sebagai keseimbangan antara invisible \& visible knowledge. Michael peragine (2020), mengatakan ada faktor lain yang menjadi concern utama, yaitu Hubungan antara kelelahan pendidik dan variabel konteks tertentu seperti kelelahan emosional, depersonalisasi, dan prestasi pribadi yang rendah. Hal ini dapat diatasi dengan tiga prinsip motivasi: mengelola emosi, bergabung dengan komunitas, meningkatkan efektivitas masing-masing.

Bidang Politik/Hukum- Pemerintah dapat membuat regulasi yang mendukung implementasi teknologi informasi sebagai sarana utama proses belajar, lebih jauh lagi, proses ini harus bersifat flesifel dan adaptif, dimana hasil dari proses belajar adalah memberikan kontribusi kepada masyarakat apapun itu, baik itu konsep/ide, inovasi ide, produk atau jasa yang telah dibentuk dari sebuah proses belajar mengajar di sekolah/universitas.

Bidang Ekonomi- pada saat siswa, mahasiswa dapat berkontribusi kepada masyarakat dari hasil pendidikannya, maka akan dihasilkan sesuatu yang bermanfaat dan ini kemungkinan besar akan dapat memperluas lapangan kerja, meningkatkan perekonomian karena diciptakannya produk/jasa yang dapat digunakan oleh masyarakat baik itu secara national atau international, dan terakhir dapat meningkatkan tingkat kompetensi dan jaringan yang lebih luas.

Tahap kedua

Pada sisi kiri terdapat lingkaran yang terdiri dari education dan globalization, sedangkan pada sisi kanan terdapat empat kategori pendidik, yang terdiri dari tipe 1-open lecturer, tipe 2-blind lecturer, tipe 3-hidden lecturer, dan tipe 4-unknown lecturer. Keempat tipe ini merupakan pengembangan metode komunikasi 
dari Johari windows, yang kemudian kami menciptakan inovasi dalam konsep, dengan membaginya menjadi empat tipe. Adapaun penjelasannya adalah sebagai berikut:

Pendidikan yang terdiri dari sekolah/universitas dihubungkan dengan globalisasi- perkembangan globalisasi sangat pesat dan perubahan yang terjadi, kita tentunya sudah mengetahui semuanya, tetapi ada satu hal penting yang perlu dipahami: "perubahan hanya dapat dihadapi dengan perubahan yang signifikan, bukan dengan perubahan yang pelan-pelan", karena hal ini untuk mengimbangi kecepatan dari perubahan global. Oleh sebab itu, untuk dapat mengimbangi kecepatan global, harus ada perubahan signifikan bukan setengah perubahan. Sekali lagi, sekolah, universitas, pendidik baik pendidik ataupun pendidik harus sudah dapat memiliki-menerapkan dan memberikan kontribusi dengan menghasilkan keseimbangan antara invisible dan visible knowledge.

Sekarang, kita masuk kepada penjelasan mengenai keempat tipe pendidik. Perlu dipahami di sini, penamaan dari kata open, blind, hidden, unknown adalah diambil dari konsep Johari windows, oleh sebab itu kami akan mengubahnya menjadi Global lecturer (G-type), Common lecturer (C-type), Silent lecturer (S-type) dan Unkown lecturer (U-type). Jika ini dihubungkan dengan formula E=KM.C2, maka menghasilkan gambar sebagai berikut:

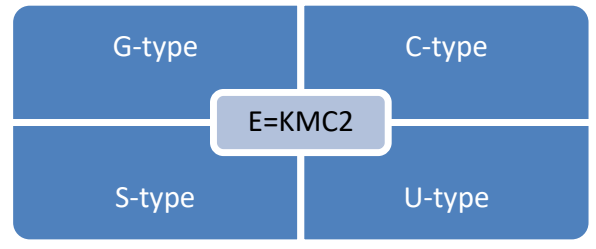

Gambar 6. Hubungan antara formula dan empat tipe lecturer

Gambar 6, menjelaskan, empat tipe lecturer, antara lain:

G-type- adalah merupakan tipe pendidik yang memiliki kemampuan tinggi dalam bidangnya, memiliki spesialiasi di bidangnya, artinya kemampuan ini memberikan dampak positif pada saat proses belajar mengajar. Ciri utamanya adalah keseimbangan antara mengajarkan pengetahuan yang "perlu" didengar oleh siswa dan kemudian dapat menghubungkannya dengan pengalamannya, sehingga siswa mendapatkan pengetahuan umum dan pengetahuan khusus. Tipe ini juga dapat menjelaskan contoh studi kasus, dan asumsi yang dihubungkan dengan logika-konsep/teori-data yang dimilikinya sehingga menghasilkan sebuah inovasi dan pemikiran yang lebih luas dan global thinking, memiliki semangat yang tinggi dalam mengajar dan siswa selalu merasakan serta mendapatkan hal positif dari lecturer ini, memberikan nasehat yang berguna untuk masa depan siswa, membangun hubungan baik dengan institusi pendidikan dan juga siswa, komunikasi yang terbuka tetapi memiliki batas-batasan tertentu, mengembangkan karakter siswa dan memberikan contoh kehidupan sehingga dapat digunakan sebagai pedoman pengembangan diri siswa, kemampuan seimbang yaitu memiliki pengalaman di bidangnya dan kemudian mengajarkannya, kemampuan dalam berkolaborasi dengan baik dengan semua pihak, easy going tetapi memiliki batasan tertentu. Ciri ini tentunya belum mutlak, tetapi masih dapat terus dikembangkan untuk memenuhi kebutuhan secara global. Patricia miller (1987), mengatakan terdapat ciri-ciri utama dari seorang pendidik yang baik, antara lain: Saya ingin seorang pendidik yang memiliki antusiasme, Saya ingin seorang pendidik yang kreatif, Saya ingin seorang pendidik yang dapat menambah kecepatan belajar dan humor di kelas, Saya ingin seorang pendidik yang menantang saya untuk berinovasi dan belajar, Saya ingin seorang pendidik yang memberi semangat dan sabar, dan yang tidak akan menyerah pada saya, Saya ingin seorang pendidik yang akan menaruh minat pada saya sebagai pribadi, Saya ingin seorang pendidik yang memahami tata bahasa dengan baik dan yang dapat menjelaskan sesuatu saat itu juga, Saya ingin seorang pendidik yang akan meluangkan waktu satu atau dua menit untuk menjawab pertanyaan setelah kelas, Saya ingin seorang pendidik yang akan memperlakukan saya sebagai pribadi, atas dasar kesetaraan dengan semua anggota kelas, Saya ingin seorang pendidik yang memiliki kecerdasan emosional yang tinggi[9]. Russell L. Herman (2011), mengatakan terdapat dua poin yang dapat dijelaskan sebagai berikut: (a) Ajarkan Materi dengan Baik- antusias dan menarik, interaktif, communicator luar biasa, mendorong pertanyaan, terorganisir, menantang dan memotivasi, memiliki ekspektasi yang tinggi terhadap tujuan yang dapat dicapai, inovatif, melek teknologi, mampu menggunakan teknologi secara efektif; (b) Pahami Siswa-peduli - benar-benar peduli dengan siswa di semua tingkatan, mempelajari nama, menghadiri pertemuan klub, bertemu di luar kelas, tunjukkan minat pada siswa. Pahami perubahan generasi, dengarkan siswa, hormati siswa, advise and mentor - membuat hubungan pribadi dengan siswa, hubungan baik, mudah didekati, humor, hygenic, sabar, mendorong siswa untuk memiliki pembelajaran seumur hidup[10]. Michael Jackson (2006), mengatakan Sebuah studi 
nasional dilakukan dengan harapan dapat mempengaruhi pendekatan pengajaran di universitas Australia. Itu mencakup daftar ciri-ciri pengajaran yang baik: mendengarkan siswa, antusiasme untuk subjek tersebut, penyesuaian untuk siswa, mendorong pendekatan pembelajaran yang mendalam, menetapkan tujuan yang jelas menawarkan umpan balik, menghormati siswa[11]. Terakhir, Samy A Azer (2005), mengatakan, dua belas kualitas pendidik atau mentor yang baik meliputi: berkomitmen untuk bekerja, mendorong dan menghargai keberagaman, berinteraksi dan mengomunikasikan rasa hormat, memotivasi siswa dan rekan kerja, membawa berbagai keterampilan dan bakat untuk mengajar, menunjukkan kepemimpinan dalam mengajar, mendorong lingkungan belajar yang terbuka dan percaya, menumbuhkan pemikiran kritis, mendorong kerja kreatif, menekankan kerja tim, berusaha terus meningkatkan keterampilan mengajar, memberikan umpan balik yang positif[12].

C-type- adalah merupakan tipe yang memiliki kemampuan lima puluh persen dari G-type. Perbedaannya adalah tipe pendidik ini kurang dapat memberikan motivasi atau care terhadap siswa, sehingga siswa di satu sisi menghormatinya karena kemampuan yang dimilikinya, tetapi untuk komunikasi masih dirasa kurang. Kompetensi dari tipe ini juga menyamai G-type, hanya satu kekurangannya yaitu caranya berkomunikasi. Feng Su (2012), mengatakan, Pendidik yang baik membekali mahasiswanya dengan berbagai alat untuk menjadi mahir dalam mata pelajaran ini dan untuk dapat melihat relevansinya. Jadi menurut saya kualitas yang paling penting dalam diri seorang pendidik ilmu sosial adalah kemampuan untuk mengaitkan teori akademik dengan kehidupan nyata dan mampu melihat setiap sisi argumen. Mereka juga harus dapat mengesampingkan keyakinan pribadinya agar siswa dapat menemukan posisinya sendiri dalam diskusi[13].

S-type- adalah merupakan tipe pendidik yang memiliki kemampuan dua puluh lima persen, dimana bekerja sebagai pendidik tetapi belum memberikan kontribusi yang lebih terhadap dunia pendidikan dan masyarakat.

U-Type adalah merupakan tipe pendidik yang belum memberikan kontribusi.

Pada intinya adalah semua pendidik memiliki kompetensi dan keunikkannya masing-masing, kita tidak bisa mengkotak-kotakkan kemampuan seseorang, tetapi kita bisa mengembangkan kompetensi pendidik dan siswa dengan cara menggabungkan antara formula $\mathrm{C}$ (competency) $=(\mathrm{E}=\mathrm{K} \cdot \mathrm{MC} 2)+(\mathrm{H}=\mathrm{GP} 2)$, formula ini jika disatukan akan menghasilkan sumber daya manusia dengan level kompetensi yang tertinggi, dimana penggabungan antara pengalaman dan pengetahuan akan menjadi satu serta tidak dipisahkan dan berdiri sendiri. Hal ini digambarkan sebagai berikut:

Tahap 1

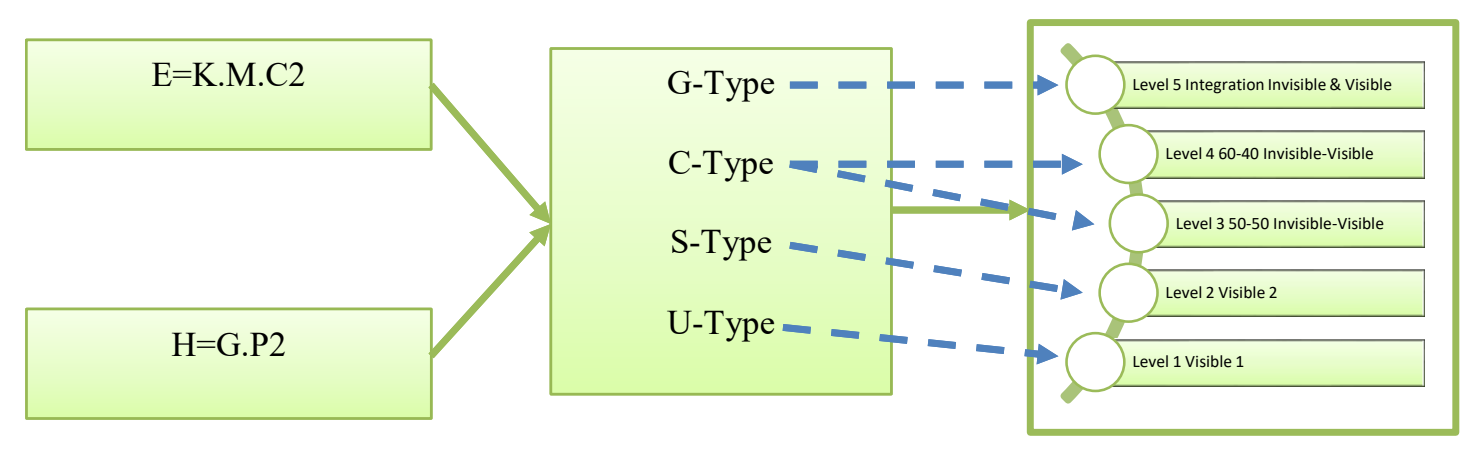


Tahap 2

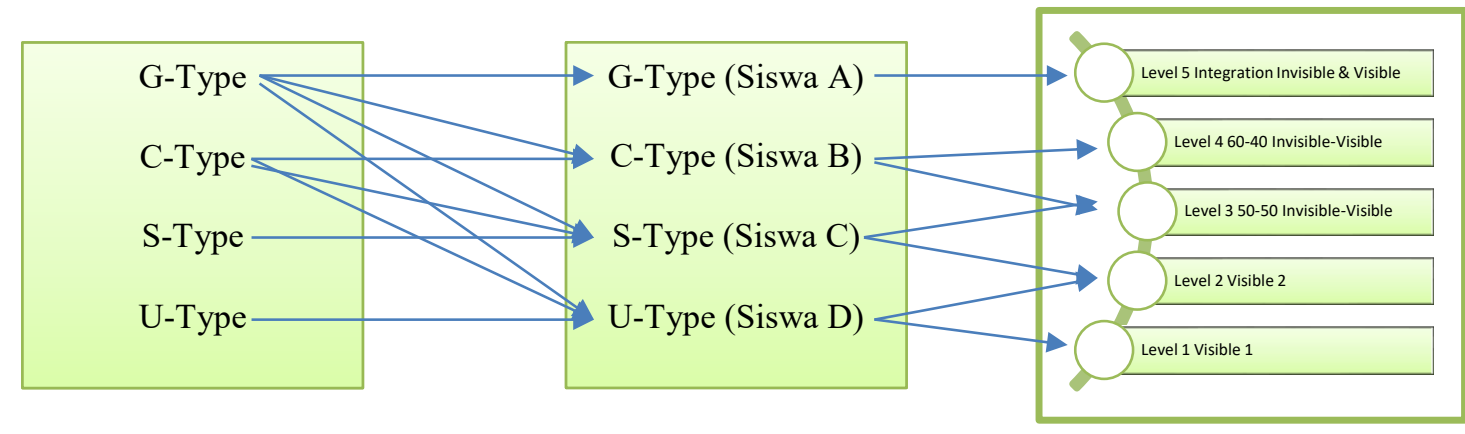

Gambar 7. Peningkatan level dan gabungan kompetensi

Gambar 7, menjelaskan hubungan antar kedua formula dan empat tipe pendidik, dimana dihubungkan dengan lima level meningkatkan kompetensi. Hal ini juga bisa digunakan untuk siswa.

Pada tahap 1, dijelaskan bahwa e merupakan energi, atau dapat dikatakan sebagai kekuatan dari organisasi, $\mathrm{k}$ adalah pengetahuan, di sini pengetahuan dapat bersifat umum dan khusus, dimana pada formula ini, masih secara gambaran besar, $\mathrm{m}$ adalah marketing, dimana organisasi membangun brand yang kuat, $\mathrm{c}$ adalah mengenai teknologi yang digunakan. Inti dari formula ini adalah bahwa organisasi harus memiliki empat hal penting: energi (kekuatan), pengetahuan, pemasaran dan teknologi. Berikutnya jika kita lihat, terdapat satu formula lagi, $\mathrm{h}$ adalah human resource atau sumber daya manusia yang secara spesifik dibagi menjadi empat kategori yang terdapat pada pendidik dan siswa, g adalah great lecturer, artinya pendidik terbaik, $\mathrm{p}$ adalah performance, dimana ini merupakan ukuran kinerja dari pendidik dan siswa, kinerja ini dibagi menjadi dua level, yaitu p1 yang disebut sebagai high level performance, dimana pendidik dan siswa memilik kinerja yang tinggi dalam belajar dan menghasilkan sesuatu dari proses belajar mengajarnya, sedangkan $\mathrm{p} 2$ adalah keseimbangan antara pengalaman dan pengetahuan yang kemudian terdapat kontribusi dengan menciptakan inovasi konsep, produk/jasa tertentu.

Pada tahap 1, kita juga melihat hubungan antara keempat tipe pendidik dengan lima level. U-type dihubungkan dengan level 1, demikian juga dengan s-type yang dihubungkan dengan level 2, ini mengartikan bahwa pendidik berada di level 1 dan 2, merupakan pendidik yang hanya berfokus pada teoritis dan kontribusi yang diberikan adalah memberikan pengetahuan yang ingin dan wajid diketahui oleh siswa, tetapi belum menyentuh kepada level apa yang perlu didengar dan diperlukan oleh siswa setelah lulus. Hal ini baik dalam hal pengetahuan tetapi masih dirasa kurang dalam meningkatkan kompetensi. Pertanyaannya: bagaimana cara meningkatkan level ini?, pertama, pendidik memberikan small project kepada siswa yang bersifat internal, artinya project tersebut dapat dihubungkan dengan kebutuhan dari institusi baik itu sekolah atau universitas. sebagai contoh, institusi membutuhkan aplikasi untuk proses belajar mengajar secara online, dan mungkin institusi sudah memiliki, tetapi masih belum sempurna, oleh sebab itu dibutuhkan pengembangan lebih lanjut. Ivana Bestvina Bukvić (2020), mengatakan: "Proyek didefinisikan sebagai setiap rangkaian kegiatan dan tugas yang memiliki tujuan tertentu yang harus memenuhi spesifikasi tertentu, memiliki awal dan akhir tertentu, sumber daya terbatas, menghabiskan sumber daya (baik manusia maupun teknis) dan bersifat multifungsi"[14].

Pendidik tipe $\mathrm{U}$ dan $\mathrm{S}$ ini dapat berkontribusi dengan membantu menyelesaikan project tersebut dan dapat digunakan sebagai tugas dari sekolah atau perkuliahan, sehingga hal ini berguna untuk meningkatkan invisible knowledge, atau institusi membutuhkan ide inovasi ataupun konsep yang berguna untuk meningkatkan brand nya, maka pendidik dan siswa dapat membuat sebuah perancangan prototype dan konsep dalam meningkatkan hal tersebut, yang kemudian merekomendasikannya kepada institusi. Jika hal ini berhasil, maka $\mathrm{S}$ dan $\mathrm{U}$ type dapat meningkat ke level 3.

Berikutnya, masih berada pada tahap 1, C type berada di dua level, yaitu level 3 dan 4, dimana level ini merupakan medium project, artinya pendidik dan siswa menyelesaikan satu buah project yang dapat berguna dan memiliki fungsi penting. Sebagai contoh, seperti yang telah dijelaskan sebelumnya, proses belajar secara online sudah berjalan tetapi masih membutuhkan pengembangan. Pendidik dan siswa dapat membantu menyempurnakan belajar online tersebut dengan melengkapi selengkap lengkapnya, apa yang masih kurang di dalam aplikasi tersebut, hal ini dapat berada di level 3, dimana pendidik dan siswa berhasil menyelesaikan medium project tersebut. Sedangkan pada level 4, medium project ini meningkat 
menjadi tingkat daerah, artinya aplikasi belajar online tersebut dapat digunakan di beberapa institusi yang berada di satu daerah, misal, institusi A sudah berhasil menyelesaikan aplikasi ini, maka A dapat menawarkan kepada B untuk menggunakannya juga dan juga demikian kepada C. Pada tahap akhir yaitu level 5, aplikasi ini dapat ditingkatkan menjadi tingkat nasional, artinya dapat digunakan di beberapa kota dan level tertinggi adalah digunakan pada satu atau dua kota di tingkat international. Pada level 5 ini juga harus terdapat integrasi data, artinya pada saat aplikasi ini digunakan, maka harus terdapat akses dan pertukaran materi pembelajaran atau informasi apapun yang berada di institusi lainnya, artinya pendidik dan siswa dapat mengakses materi pembelajaran, tugas akhir, kerja praktek atau lainnya, agar terjadi pertukaran pengetahuan. Youssef M. Abu Amuna (2017), mengatakan: "Strategi Manajemen Hubungan Pelanggan melampirkan tiga dimensi dasar organisasi: filosofi, teknologi, dan strategi. Selain itu, keberhasilan strategi Manajemen Hubungan Pelanggan bergantung pada stabilitas yang benar antara tiga sumber daya organisasi yang signifikan: proses, teknologi, dan orang-orang'[15]. Lebih jauh lagi, Sándor Suplicz (2009), mengatakan, Metode praktis pengembangan keterampilan pedagogis - observasi kelas, pengajaran mikro, praktik pedagogis dan pengajaran, analisis kasus, diskusi kelompok tentang pengalaman, memiliki efek formatif melalui refleksi mereka tidak hanya pada struktur kognitif tetapi juga tentang kepribadian[16]. Diana Mitova (2018), mengatakan, Mata pelajaran sekolah "Teknologi dan kewirausahaan" adalah bagian dari struktur pendidikan umum di Bulgaria dan diajarkan di sekolah di sekolah dasar dan tingkat menengah. Mata pelajaran difokuskan pada memperoleh keterampilan yang memungkinkan siswa untuk bereaksi terhadap hal-hal baru, mengambil tanggung jawab, menjadi kompeten, inisiatif dan berorientasi bisnis. Pendekatan modern untuk mengajarkan pengetahuan ekonomi teknologi dasar, serta organisasi dan inisiatif dalam keterampilan kerja, termasuk dalam konten pembelajaran. Beberapa pendekatan modern yang diaplikasikan dalam pembentukan kesadaran teknologi adalah belajar dengan pendekatan pencarian dan penemuan serta pendekatan integrasi modul. Organisasi teknologi dan pendidikan kewirausahaan mencakup pelajaran dan kelas terintegrasi, di mana kerja tim dan proyek dapat ditoleransi[17]. Zoriana Krykhovetska (2020), mengatakan, Manfaat berpartisipasi dalam proyek hibah internasional adalah sebagai berikut: Pelaksanaan hasil penelitian, melakukan penelitian dengan menggunakan peralatan modern mitra luar negeri, kemungkinan mempublikasikan hasil penelitian di tingkat internasional, publikasi (high impact factor), termasuk bersama dengan rekan asing, memastikan kerjasama internasional dengan sekolah ilmiah terkemuka, materi dorongan pelaku, faktor menjaga kualitas hasil ilmiah karena daya saing proyek ilmiah, presentasi hasil penelitian kepada komunitas ilmiah dunia, kemungkinan penyiaran modal ilmiah di bidang sains, pengakuan komunitas ilmiah atas pencapaian yang relevan ilmuwan, menaikkan peringkat ilmuwan dalam struktur umum bidang ilmiah[18].

Tahap 2, pada tahap ini terlihat pada gambar, bahwa u type dihubungkan dengan siswa $\mathrm{D}$, dan kemudian dihubungkan dengan level 1 dan 2, sedangkan s type dihubungkan dengan siswa $\mathrm{C}$ dan berada di level 2 dan 3. Hal ini dapat dihubungkan dengan tugas perkuliahan yang memiliki kontribusi, artinya tugas-tugas yang selama ini terjadi bersifat tetap dan mungkin masih membutuhkan kreativitas, dimana untuk menghadapi globalisasi, maka perubahan itu diperlukan. Pada level ini, pendidik memberikan tugas kepada siswa dari penelitian yang telah diselesaikan dan dipublikasikannya, siswa dan pendidik mengembangkan artikel tersebut menjadi lebih sempurna dan kemudian mempublikasikannya di jurnal nasional atau internasional. Hal ini berguna agar siswa juga memperoleh manfaat dan meningkatkan analisis terhadap sesuatu serta dapat meningkatkan kompetensi pengetahuannya. Kontribusi siswa D dan $\mathrm{C}$ adalah menghasilkan sebuah publikasi jurnal nasional atau internasional ataupun sebuah produk/jasa tertentu yang didapat dari penelitian sebelumnya, yang dikembangkan serta menghasilkan sesuatu.

Pada c type berada di level 3 dan 4, artinya level ini meningkat menjadi proses medium project, artinya pendidik dan siswa melakukan pengabdian masyarakat bersama-sama di suatu tempat, dan tempat tersebut, kemudian memberikan kontribusi kepada tempat tersebut. Pada level 3, kontribusi dapat diberikan di daerah masing-masing, sedangkan pada level 4, dapat diberikan di tingkat nasional. Hal yang perlu dipertimbangkan di sini adalah biaya dan lokasi, jika hal ini sekiranya memberatkan pendidik dan siswa, maka dapat diubah menjadi sebuah project. Sebagai contoh, pendidik dan siswa dapat menghasilkan sesuatu berupa sebuah ide atau konsep ataupun publikasi di international level, atau dapat menghasilkan produk yang dipatenkan di tingkat nasional, sehingga kontribusi tetap dapat dilakukan. Pada level 5, yaitu level tertinggi, pendidik dan siswa dapat memberikan kontribusi di level international, dimana produk/jasa yang dihasilkan dapat diakui secara international, hal ini juga dapat dilakukan kerjasama dengan industry serta memenuhi kebutuhan dan fungsi serta manfaat apa yang diperlukan oleh industry. Hal ini juga perlu mempertimbangkan biaya dan lokasi serta waktu. Jika hal ini tidak dapat 
dilakukan, maka terdapat solusi lain, yaitu menyelesaikan project bersama-sama dengan orang tua siswa, strategi ini akan dijelaskan pada pengabdian dan artikel berikutnya.

\section{KESIMPULAN}

Kesimpulan yang dapat diambil dari hasil pengabdian, pelatihan dan penelitian ini adalah:

1. 3SDP Universitas Harvard-Johari window-E $=\mathrm{K} . \mathrm{MC} 2$ dapat diterapkan di tingkat pendidikan, terutama dalam pengembangan sumber daya pendidik dan siswa. Hal ini harus diterapkan secara terus menerus, yang artinya harus terdapat konsistensi dalam jangka pendek, menengah dan panjang

2. Formula $\mathrm{H}=\mathrm{G} . \mathrm{P} 2$ adalah formula yang dapat diterapkan di tingkat sekolah menengah pertama sampai unviersitas, pendidik dan siswa telah menerapkan konsep E = K.MC2. Gabungan kedua formula ini akan dapat menghasilkan sumber daya manusia yang handal dan berkualitas tinggi

\section{UCAPAN TERIMA KASIH}

Kami berterima kasih kepada seluruh SMA Negeri 3, atas kesempatan yang telah diberikan dalam membagikan ilmu pengetahuan dan pelatihan yang diberikan untuk dapat meningkatkan kualitas sumber daya manusia. Kami juga ingin berterima kasih kepada pihakpihak yang telah membantu kami dalam memberikan masukan dan informasi yang bermanfaat dalam menyelesaikan penelitian dan pengabdian masyarakat ini.

\section{DAFTAR PUSTAKA}

[1] M. Sheehan, "Human resource management and performance: Evidence from small and medium-sized firms," Int. Small Bus. J., vol. 32, no. 5, pp. 545-570, 2014, doi: 10.1177/0266242612465454.

[2] E. E. Bennett, "Introducing New Perspectives on Virtual Human Resource Development," Adv. Dev. Hum. Resour., vol. 16, no. 3, pp. 263-280, 2014, doi: 10.1177/1523422314532091.

[3] D. McGuire, Foundations of human resource development. 2011.

[4] M. Boumadan, R. Soto-Varela, C. Poyatos-Dorado, and M. Ortiz-Padilla, "What factors determine the value of an online teacher education experience from a teacher's perspective?," Sustain., vol. 12, no. 19, pp. 1-16, 2020, doi: 10.3390/su12198064.

[5] C. Hodges, S. Moore, B. Lockee, T. Trust, and A. Bond, "Remote Teaching and Online Learning," Educ. Rev., pp. 1-15, 2020, [Online]. Available: https://er.educause.edu/articles/2020/3/the-difference-between-emergency-remoteteaching-and-.

[6] J. Strikwerda-Brown, R. Oliver, D. Hodgson, M. Palmer, and L. Watts, "Good teachers/bad teachers: How rural adolescent students' views of teachers impact on their school experiences," Aust. J. Teach. Educ., vol. 33, no. 6, pp. 29-43, 2008, doi: 10.14221/ajte.2008v33n6.3.

[7] E. Karadağ, F. Bektaş, N. Çoğaltay, and M. Yalçı, "The effect of educational leadership on students' achievement: a meta-analysis study," Asia Pacific Educ. Rev., vol. 16, no. 1, pp. 79-93, 2015, doi: 10.1007/s12564-015-9357-x.

[8] R. P. Shrivastava, Neha; Singh, "johari window approach in mentoring management 
students- an empirical study of up and uttarakhand (india)," Sch. Res. J. Interdiscip. Stud., vol. 4, no. 35, pp. 6410-6420, 2017.

[9] W. Eckerson, "Ten Characteristics of a Good KPI," Data Warehous. Inst., vol. 25, no. 1, 1987 , http://scholar.google.com/scholar?hl=en\&btnG=Search\&q=intitle:Ten+Characteristics + of $+\mathrm{a}+\mathrm{Good}+\mathrm{KPI} \# 0$.

[10] R. L. Herman, "Letter from the Editor-in-Chief: What Makes an Excellent Professor ?," J. Eff. Teach., vol. 11, no. 1, pp. 1-5, 2011.

[11] M. Jackson, “'Serving time': The relationship of good and bad teaching," Qual. Assur. Educ., vol. 14, no. 4, pp. 385-397, 2006, doi: 10.1108/09684880610703965.

[12] S. A. Azer, "The qualities of a good teacher: How can they be acquired and sustained?," J. R. Soc. Med., vol. 98, no. 2, pp. 67-69, 2005, doi: 10.1258/jrsm.98.2.67.

[13] F. Su and M. Wood, "What makes a good university lecturer? Students' perceptions of teaching excellence," J. Appl. Res. High. Educ., vol. 4, no. 2, pp. 142-155, 2012, doi: $10.1108 / 17581181211273110$.

[14] I. B. Bukvić, I. Buljubašić, and M. Ivić, "Project management education in croatia: A focus on the it sector needs," Manag., vol. 25, no. 1, pp. 255-278, 2020, doi: 10.30924/mjcmi.25.1.14.

[15] Y. M. A. Amuna, M. J. Al Shobaki, S. S. A. Naser, and J. J. Badwan, "Understanding Critical Variables for Customer Relationship Management in Higher Education Institution from Employees Perspective," ITEE J., vol. 6, no. 1, pp. 10-16, 2017.

[16] S. Suplicz, "What makes a teacher bad? - trait and learnt factors of teachers' competencies," Acta Polytech. Hungarica, vol. 6, no. 3, pp. 125-138, 2009.

[17] D. Mitova, "Diana Mitova project-based education on technology and," 2018.

[18] Z. Krykhovetska, S. Kropelnytska, and O. Kondur, "the Development of Project Activity in Higher Educational Institutions," pp. 35-36, 2020, doi: 10.36074/05.06.2020.v1.12. 